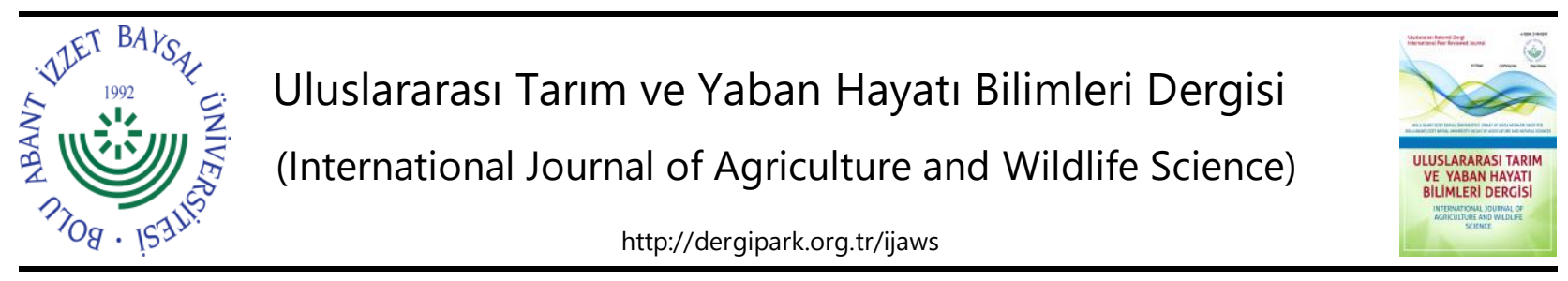

Araştırma Makalesi

\title{
Sulu ve Kuru Koşullarda Farklı Amarant Türlerine Ait Çeşitlerin Ot Verim Performanslarının Belirlenmesi
}

\author{
Süleyman Temel $^{1 *}$, Bilal Keskin ${ }^{1}$, Selma Çakmakç1， Ramazan Tosun ${ }^{2}$ \\ ${ }^{1}$ Iğdır Üniversitesi Ziraat Fakültesi Tarla Bitkileri Bölümü, Iğdır \\ ${ }^{2}$ Iğdır Üniversitesi Ziraat Fakültesi Zootekni Bölümü, Iğdır
}

Geliş tarihi (Received): 01.09.2020 Kabul tarihi (Accepted): 05.10.2020

\begin{abstract}
Anahtar kelimeler:
Özet. Farklı amaçlar (sebze, dane, süs ve yem bitkisi olarak ) için tercih edilen amarantların, ekstrem Amarant çeşitleri, Iğdır, ot verim iklim ve toprak koşullarına toleranslarının yüksek olduğu bilinmektedir. Ancak Ülkemizde yem özellikleri, yetişme koşulları amacıyla kullanılan amarant türlerinin sulu ve kuru koşullarda ot verim performanslarının değerlendirilmesine yönelik bir çalışma bulunmamaktadır. Mevcut çalışma ile farklı amarant türlerine ait çeşitlerin (Sterk, Helios ve Ultra) ot verimi ve bazı özellikleri (bitki boyu, sap kalınlığı, yaprak sayısı, yaş ot verimi, kuru ot verimi, kuru ot oranı, yaprak, sap ve salkım oranı) sulu ve kuru koşullarda belirlenmeye çalışılmıştır. Bu amaçla 2017 ve 2018 yıllarında tesadüf bloklarında bölünmüş parseller deneme deseninde 3 tekerrürlü bir çalışma kurulmuştur. Çalışma sonucunda çeşitlerin bitki boyu, sap kalınlığı, yaprak sayısı, yaprak oranı, yaş ot ve kuru ot verimleri sulu koşullarda, kuru ot oranı, sap ve salkım oranları ise kuruda daha yüksek bulunmuştur. Çeşitler

*Sorumlu yazar

stemel33@hotmail.com açısından en yüksek yaş ot ve kuru ot verimleri Helios çeşidini müteakiben Sterk çeşidinde belirlenmiştir. Ayrıca Sterk ve Helios çeşitlerinin kuru koşullarda azımsanmayacak oranda yaş ot ve kuru ot verimlerine sahip oldukları ortaya konulmuştur. Sonuç olarak yüksek ot verimleri için Sterk çeşidinin sulu koşullarda yetiştirilmesinin uygun olacağı kanısına varıımıştır.
\end{abstract}

\section{Determination of the Hay Yield Performances of Varieties Belonging to Different Amaranth Species in Irrigated and Dry Conditions}

\section{Keywords:}

Amarant varieties, Igdir, hay yield properties, growing conditions

\begin{abstract}
It is known that amaranths, which are preferred for different purposes (as vegetable, grain, ornamental and fodder crop), have high tolerance to extreme climate and soil conditions. However, in Turkey, there is no study to evaluate the hay yield performances of amaranth species used for feed in irrigated and dry conditions. With the present study, the performances of varieties (Sterk, Helios and Ultra) belonging to different amaranth species in terms of hay yield characteristics (plant height, stem thickness, number of leaf per plant, fresh and dry herbage yields, dry herbage rate, leaf, stem and panicle ratios) in irrigated and dry conditions were tried to be determined. For this purpose, in 2017 and 2018, a study with 3 replications was established according to split plot experimental design on completely randomized blocks. As a result of the study, plant height, stem thickness, leaf number, leaf ratio, fresh herbage and hay yields were found to be higher in irrigated conditions, but dry herbage rate, stem and panicle ratios in dry conditions. In terms of varieties, the highest fresh and dry herbage yields were determined in Sterk variety, following the Helios variety. In addition, it was revealed that Sterk and Helios varieties had a considerable amount of fresh and dry herbage yields in dry conditions. As a result, it has been concluded that it would be appropriate to grow the Sterk variety under irrigated conditions for high forage yields.
\end{abstract}




\section{GíRiş}

Son yıllarda küresel ısınmaya bağlı olarak artan kuraklık, pek çok bölgede ekimi yapılan bitki türlerinin ekonomik anlamda yetiştiriciliğini kısıtlamış, hatta bazı coğrafyalarda çoğu türlerin ortamdan çekilmesine neden olmuştur (Kalefetoğlu ve Ekmekçi, 2005). Bu sebepten bilim insanları canlıların yeterli ve dengeli beslenebilmesi için marjinal alanlarda yetişebilen bitki tür ve çeşitlerinin arayışı içerisine girmişlerdir (Pimentel ve ark., 2008; Tan ve Temel, 2012; Tan ve Temel, 2017). Çünkü bu türler sahip oldukları özellikleri ile ekstrem koşullara uyum sağlayarak, stres koşullarında dahi yeter miktar ve kalitede üretim yapabilmektedirler. Amaranthus cinsi içerisinde yer alan türler de, verimsiz topraklara ve kurak iklim koşullarına oldukça dayanıklı olup, yetiştiriciliği yapılan pek çok kültür bitkisinden daha fazla susuzluğa dayanabilmektedirler (Svirskis, 2003; Rezaei ve ark., 2014).

Amarant cinsi içerisinde yer alan genotiplerin çoğu yabancı ot olarak bilinse de (Khan ve ark., 2019), sebze ve tahıl (yüksek protein ve mineral içeriğinden dolayı) olarak kullanılan çok sayıda türü de bünyesinde barındırmaktadır (Svirskis, 2003; Adhikary ve ark., 2020;). Bunun yanında bazı amarant türleri gösterişli çiçek ve yaprak yapılarından dolayı peyzaj bitkisi olarak da değerlendirilmektedir (Mlakar ve ark., 2009; Venskutonis ve Kraujalis, 2013). Ayrıca amarant türlerinin çoğu ekstrem iklim ve toprak koşullarına toleransı yüksek olup, marjinal alanların üretime kazandırılmasında ve yem bitkisi olarak kullanımında önemli avantajlara sahiptir. Özellikle düşük ekim normu ile birim alanda ürettiği kuru madde miktarı (1600 kg da $\left.{ }^{-1}\right)$ ve yem kalitesinin yüksek olması, kısa vejetasyon süresine ve yüksek yaprak oranına sahip olması nedeniyle amarant türlerinin çoğu hayvan beslenmesinde alternatif yem kaynağı olarak uygun görülmüşlerdir (Acar ve ark., 1999; Svirskis, 2003; Alegbejo, 2013; Sarmadi ve ark., 2016; Leukebandara ve ark., 2019). Sahip olduğu bu özelliklerinden dolayı son yıllarda Amarant türlerine olan ilgi artmış (Peiretti ve ark., 2018) ve farklı amaçlar doğrultusunda çok sayıda bilimsel (adaptasyon, tarımsal v.b.) çalışmalar yürütülmüştür. Araştırma sonuçları amarant tür ve çeşitlerinin ekolojik koşullara ve kültürel uygulamalara aynı tepkiyi göstermediğini ve bu nedenle de birim alandan elde edilen kuru madde verimlerinin farklılık gösterdiğini ortaya koymuştur. Mevcut bu sonuçlar göz önünde bulundurularak farklı coğrafyalar için yüksek ot verimine sahip amarant tür ve çeşitlerin belirlenmesi önemlilik arz etmektedir.

Her ne kadar yüksek ot verimlerinin sağlanmasında çeşit seçimi önemli bir faktör ise de, ekim normu, gübreleme ve sulama gibi tarımsal uygulamaların da önemli etkisi bulunmaktadır. Nitekim öncesinde yapılan çalışmalarda birim alandan elde edilen verimlerin ekim normu (Sokoto ve Johnbosco, 2017) ve gübre doz uygulamalardan etkilendiği (Abbasi ve ark., 2012; Dumanoğlu ve Geren, 2019; Dlamini ve ark., 2020) ortaya konulmuş ve farklı ekolojiler için uygun ekim normu ve gübre dozları belirlenmeye çalışıımıştır. Diğer taraftan kuraklık stresi (su eksikliği) bitkiyi morfolojik, fizyolojik ve biyokimyasal yönden etkileyerek (Anjum ve ark., 2011; Gao ve ark., 2020) birim alandan elde edilen verimlerin düşmesine neden olmaktadır. Her ne kadar amarantlar susuzluğa dayanıklı olsa da, tüm türlerin kuraklık stresine tepkisi aynı değildir. Bazı genotiplerin su kullanım etkinliği daha yüksek iken, bazı genotiplerin daha düşük olabilmektedir (Liu ve Stutzel, 2004). Bu da yetişme koşullarına (sulu ve kuru) göre bitkilerin verimlerini önemli oranda etkileyebilmektedir. Bu nedenle bölge ekolojisine uygun yüksek verimler üretebilen tür ve çeşitlerin belirlenmesi amacıyla adaptasyon çalışmalarının bir an önce tamamlanması önem arz etmektedir. Nitekim sebze ve dane amarantlarda kuraklık stresi ile ilgili çok sayıda araştırma yürütülmüş ve kuraklık stresinin (su eksikliğine bağlı olarak) artmasıyla çeşitlere bağlı olarak verimlerde önemli düşüşlerin yaşandığı ortaya konulmuştur (Da Silva ve ark., 2019; Grantz ve ark., 2019). Ancak yem amacıyla kullanılan amaranlarda bu tür çalışmalar yok denecek kadar azdır. Sadece Ahrar ve ark. (2020) tarafından 3 farklı yem amarantında farklı sulama seviyelerinin etkisi test edilmiş ve çalışma sonucunda yarayışı suyun \%80'ni tüketildiğinde yapılan sulama ile yaş ve kuru ot verimlerin sırasıyla \%62 ve \%50 oranında azaldığı belirlenmiştir. Yem amarantları ile az sayıda yürütülen çalışmalarda da genotiplere bağı olarak yaş ve kuru ot verimlerinde \%50'nin üzerinde düşüşlerin yaşandığı rapor edilmiştir. Ancak ülkemizde farklı yetişme koşulları (sulu ve kuru) baz alınarak öncesinde amarant türleriyle yürütülmüş bir çalışma bulunmamaktadır. Ayrıca mevcut çalışmada incelemeye alınan türlerle ilgili hiçbir adaptasyon çalışması yapılmamıştır.

Mevcut çalışma ile sulu ve kuru koşullarda yetiştirilen Amaranthus caudatus, Amaranthus hiybridus ve Amaranthus paniculatus x Amaranthus nutans türlerine ait çeşitlerin ot verim özelliklerinin belirlenmesi amaçlanmıştır. Böylelikle sulu ve kuru koşullarda yüksek ot verim performansı gösteren çeşitler ortaya konulmuş olacaktır.

\section{MATERYAL VE METOT}

Mevcut araştırma iki yıl süreyle (2017 ve 2018) Türkiye'nin Kuzey Doğusunda yer alan mikro iklim özelliğe sahip Iğdır İlinde yürütülmüştür. Araştırmanın yürütüldüğü bölgenin bazı iklim değerleri Çizelge 1'de sunulmuştur (MGM, 2019). Çizelge 1 incelendiğinde, uzun yıllar ortalamasına göre denemenin yürütüldüğü 2017 ve 2018 yılı 
daha kurak geçmiştir. Ayrıca denemenin yürütüldüğü 2017 yılında yağış miktarı, ortalama sıcaklık ve nispi nem 2018 yılına göre daha düşük ölçülmüştür (MGM, 2019). Her iki yılda da ekim öncesi deneme sahasını temsil edecek şekilde toprak örnekleri alınmış ve yapılan analiz sonucu araştırma sahası topraklarının; orta alkali ( $\mathrm{pH}$ : 8-25-8.45) karakterde, tuz (1.43-1.53 dS/m), organik madde (\%1.06-1.15), elverişli fosfor (2.29-2,59 ppm) ve potasyum (1.661.90 ppm) içeriği düşük, kireç içeriği yüksek (\%10.7-11.4), kalsiyum (15-18 ppm) ve magnezyum (6.2-7.0 ppm) içeriği ise orta seviyede bulunmuştur (Kacar, 2012). Mevcut çalışmada farklı amarant türlerine ait üç çeşit (Sterk, Ultra ve Helios) ve iki yetişme koşulu (sulu ve kuru) kullanılmıştır. Amaranthus hybridus türüne ait olan Ultra çeşidi, kısa vejetasyon periyotları için Ukrayna'da geliştirilmiştir (Goptsiy ve ark., 2008). Helios, yağ içeriği yüksek dane tipi olup, Amaranthus caudatus'a ait bir çeşittir (Yaroshko ve Kuchuk, 2018). Sterk çeşidi ise Amaranthus paniculatus $x$ Amaranthus nutans türlerinin melez tohumlarına kimyasal mutagen uygulanarak, yüksek nem ve sıcaklık stresine dayanıklı bir çeşit olarak geliştirilmiş̧ir (Jafari ve ark., 2018).

Çizelge 1. Araştırma sahasının bazı iklim özellikleri.

Table 1. Some climatic characteristics of the research area.

\begin{tabular}{lccccccccc}
\hline \multirow{2}{*}{ Aylar } & \multicolumn{3}{c}{ Toplam yağış miktarı $(\mathbf{m m})$} & \multicolumn{3}{c}{ Ortalama sıcaklık ( $\left.{ }^{\circ} \mathbf{C}\right)$} & \multicolumn{3}{c}{ Ortalama nispi nem (\%) } \\
\cline { 2 - 10 } & UYO* & $\mathbf{2 0 1 7}$ & $\mathbf{2 0 1 8}$ & UYO & $\mathbf{2 0 1 7}$ & $\mathbf{2 0 1 8}$ & UYO & $\mathbf{2 0 1 7}$ & $\mathbf{2 0 1 8}$ \\
\hline Mart & 22.3 & 11.4 & 16.5 & 6.9 & 6.7 & 12.3 & 49.6 & 59.9 & 51.9 \\
Nisan & 38.4 & 18.1 & 18.2 & 13.4 & 13.4 & 14.2 & 49.0 & 47.2 & 49.6 \\
Mayıs & 48.7 & 57 & 69.1 & 17.5 & 18.6 & 18.4 & 51.0 & 54 & 65.5 \\
Haziran & 33.9 & 8.2 & 31.8 & 22.3 & 24.2 & 23.4 & 45.7 & 42.9 & 54.5 \\
Temmuz & 15.0 & 5.3 & 5.8 & 26.1 & 28.0 & 29.2 & 43.3 & 41.9 & 42.8 \\
\hline Toplam/Ortalama & 158.3 & 100.0 & 141.4 & 17.2 & 18.2 & 19.5 & 47.7 & 49.2 & 52.9 \\
\hline
\end{tabular}

*, Uzun yıllar ortalaması.

Tesadüf bloklarında bölünmüş parseller deneme desenine göre 3 tekerrürlü olarak kurulan bu çalışmada, ana parsellere yetişme koşulları (sulu ve kuru), alt parsellere ise çeşitler yerleştirilmiştir. Ana parseller ve bloklar arasında $5 \mathrm{~m}$, alt parseller arasında ise $1.2 \mathrm{~m}$ boşluk bırakılarak, her bir alt parselin alanı $9.8 \mathrm{~m}^{2}(3.5 \mathrm{~m} \times 2.8 \mathrm{~m})$ olarak ayarlanmışıı. Tohumlar $70 \times 15 \mathrm{~cm}$ sıra aralığı ve üzeri mesafede olacak şekilde $1.5 \mathrm{~cm}$ ekim derinliğinde markörle açılan çizilere elle ekilmişlerdir (Svirskis, 2003). ilk yılki ekimler 14.04.2017 tarihinde, ikinci yıl ekimleri ise 25.03.2018 tarihinde gerçekleştirilmiştir. Ekim tarihlerindeki bu farklılık toprak ve iklim koşullarının ekim için uygun olmamasından kaynaklanmıştır. Toprak analiz sonuçları göz önünde bulundurularak ekim öncesi dekara $10 \mathrm{~kg}$ saf $\mathrm{P}_{2} \mathrm{O}_{5}$ (\%46'lık triple süper fosfat) ve $5 \mathrm{~kg}$ saf $\mathrm{N}$ (\%21'lik amonyum sülfat) gelecek şekilde gübreleme yapılmıştır. Ayrıca bitkiler $30 \mathrm{~cm}$ ulaştıklarında ilave $5 \mathrm{~kg}$ daha saf azot verilmiştir. (Myers, 1996; Genç ve Acar, 2009). Sulu koşullarda topraktaki yarayışlı suyun \%50'si tüketildiği zamanda tekrar tarla kapasitesine gelecek şekilde yağmurlama sulama yöntemiyle sulama yapılmıştır. Ancak kuruda doğal yağış koşulları atında bitkilerin gelişmesi sağlanmış ve hiçbir sulama yapılmamıştır. Yetişme süresi boyunca deneme sahasında görülen yabancı otlar elle çekme ve çapalama yöntemiyle kontrol altına alınmıştır.

Çeşitlerin ot hasatları $7.5 \mathrm{~cm}$ toprak seviyesinde olacak şekilde çiçeklenme başlangıında elle yapılmıştır (Fazaeli ve ark., 2011; Leukebandara ve ark., 2015). Ancak çeşitlerin ot hasatları yıllara ve yetişme koşullarına göre farklı tarihlerde gerçekleşmiştir. Her iki yılda da kuru koşullarda ilk biçim olgunluğuna gelen çeşit Ultra (ilk yıl; 01.07.2017, ikinci yıl; 20.06.2018) olmuş ve bunu sırasıyla ortalama 10'ar gün aralıklarla Sterk ve Helios çeşitleri takip etmiştir. Ayrıca her iki yılda da suludaki çeşitler, kuru koşullara göre ortalama bir hafta daha geç hasat edilmişlerdir.

Hasat öncesi her bir parselden hasat alanı içerisinden rastgele 10 bitki seçilmiş ve seçilen 10 bitki üzerinden çeşitlerin ortalama bitki boyları $(\mathrm{cm})$, ana sap kalınlıkları $(\mathrm{mm})$ ve bitkide yaprak sayımları (adet) yapılmıştır. Daha sonra kenarlardan birer sıra ve parsel başlarından da $0.5 \mathrm{~m}^{\prime}$ lik alan kenar tesiri olarak bırakılarak, $3.5 \mathrm{~m}^{2 \prime}$ lik alan hasat edilmiştir. Hasat sonrası bitkiler sap, yaprak ve salkımlarından ayırt edilerek ayrı ayrı yaş ağırlıkları ölçülmüştür. Sonra bu kısımların ağırlıkları toplanarak önce toplam yaş ağırlıkları, sonrasında ise dekara yaş ot verimleri $\mathrm{kg}$ cinsinden belirlenmiştir. Daha sonra ayırt edilen bitki kısımları açık havada 3-4 gün soldurulduktan sonra $70^{\circ} \mathrm{C}$ 'ye ayarlı kurutma fırınında ağırlıkları sabit oluncaya kadar yine ayrı ayrı kurutulmuş ve sonrasında ise toplam kuru ağırlıkları hesaplanarak, dekara kuru ot verimleri kg cinsinden tespit edilmiştir. En sonunda ise kuru ot verimleri yaş ot verimlerine oranlanarak, çeşitlerin kuru ot oranları hesaplanmıştır (Olorunnisomo ve Ayodele, 2009). Bitkilerin yaprak, sap ve salkım ağırlıkları toplam bitki ağılığına oranlanarak da yaprak, sap ve salkım oranları belirlenmiştir.

Araştırma sonucunda elde edilen değerler tesadüf bloklarında yıl tekrarlamalı bölünmüş parseller deneme desenine göre JMP 5.0.1 istatistik paket programında varyans analizine tabi tutulmuş ve önemli çıkan ortalamaların gruplandırıması LSD testine göre yapılmıştır. 


\section{BULGULAR VE TARTIŞMA}

Amarant türlerine ait çeşitlerin sulu ve kuru koşullardaki ot verim performanslarını ortaya koymak amacıyla yürütülen bu çalışmada; istatistik analiz sonucu üçlü interaksiyonların önemli çıktığı bitki boyu, bitki başına yaprak sayısı, yaş ot verimi, kuru ot verimi, sap ve salkım oranlarına ait parametrelerde ikili interaksiyonlar, ikili interaksiyonların önemli çıktığı kuru ot oranı ve yaprak oranına ait parametrelerde ise ana faktörler üzerinde ayrı ayrı durulmamış, veri sunumu ve tartışması önemli çıkan interaksiyonlara göre yapılmıştır. Ayrıca hiçbir interaksiyonun önemli çıkmadığı ana sap kalınlığında veri sunumu ve tartışması ana faktörler üzerinden gerçekleştirilmiştir.

\section{Bitki Boyu(cm) ve Bitki Başına Yaprak Sayısı (adet)}

Sulu ve kuru koşullarda farklı amarant çeşitlerinin test edildiği bu çalışmada, bitki boyu ve bitki başına yaprak sayısı üzerinde yıl $x$ yetişme koşulu $x$ çeşit interaksiyonu istatistiki olarak önemli bulunmuştur $(P \leq 0.01)$. Bitki boyu açısından en yüksek değer 2018 yılında sulu koşullarda yetiştirilen Helios $(119.4 \mathrm{~cm})$ 'da, en düşük boylanma ise 2017 ylında kuruda yetiştirilen Ultra çeşidinde $(44.5 \mathrm{~cm}$ ) belirlenmiştir (Çizelge 2). Bu, 2017 yılına göre 2018 yılında, kuru koşullara göre suluda bitkilerin kuraklık stresine maruz kalmaması ve bitki gelişimi açısından optimum koşulların olmasından kaynaklanmış olabilir. Çünkü su, bitkilerde hücre genişlemesi ve bölünmesi ile fotosentezi arttırarak, vejetatif gelişmeyi ve boylanmayı arttıran önemli bir çevre fatörüdür (Sağlam, 2004). Nitekim Yarnia ve ark. (2011) kuraklık stres koşullarında amarant bitkisinin daha kısa bir boylanma gösterdiğini rapor etmişlerdir. Ayrıca Ultra çeşidine göre geçci olan Helios çeşidinin ortam koşullarından daha fazla istifade etmiş olması, buna neden olmuş olabilir. Nitekim geçci çeşitler daha uzun bir gelişme süresine sahip olacağından boylanmaları daha fazla olabilmektedir (Tan ve Temel, 2019). Çizelge 2 incelendiğinde, diğer çeşitlerle kıyaslandığında Sterk çeşidinin bitki boyu 2017 yılında sulu koşullara göre kuruda daha fazla bir azalma (\%35.9 oranında) gösterirken, 2018 yılında daha düşük bir azalma (\%4.4) göstermiştir. Bu, artan kuraklıkla birlikte bitkinin su kullanım etkinliğinin düşmesinden kaynaklanmış olabilir (Taiz ve Zeiger, 2008). Çünkü çeşitlerin su kullanım etkinliği genetik yapıya bağlı olarak farklılık gösterebilmektedir (Liu ve Stutzel, 2004). Oluşan bu farklııklar üçlü interaksiyonun önemli çıkmasına neden olmuştur.

Çizelge 2. Sulu ve kuru koşullarda yetiştirilen amarant çeşitlerinin bitki boyu ve bitki başına yaprak sayıları. Table 2. The number of leaf per plant and plant height of amarant varieties grown in irrigated and dry conditions.

\begin{tabular}{|c|c|c|c|c|c|c|c|}
\hline \multirow{3}{*}{\multicolumn{2}{|c|}{ Yıllar (Y) Yetişme koşulları (YK) }} & \multicolumn{3}{|c|}{ Bitki boyu $(\mathrm{cm})$} & \multicolumn{3}{|c|}{ Bitki başına yaprak sayısı (adet) } \\
\hline & & \multicolumn{3}{|c|}{ Cesitler (C) } & \multicolumn{3}{|c|}{ Çeşitler (Ç) } \\
\hline & & Helios & Sterk & Ultra & Helios & Sterk & Ultra \\
\hline \multirow{2}{*}{2017} & Sulu & $93.1 c^{* *}$ & $100.1 \mathrm{~b}$ & $58.5 \mathrm{fg}$ & $58.3 f^{\star *}$ & 124.8 a & $68.6 \mathrm{e}$ \\
\hline & Kuru & $69.4 \mathrm{e}$ & 64.1 ef & $44.5 \mathrm{~h}$ & $53.3 \mathrm{f}$ & $73.1 \mathrm{de}$ & $28.8 \mathrm{~g}$ \\
\hline \multirow{2}{*}{2018} & Sulu & 119.4 a & $103.5 \mathrm{~b}$ & $66.5 \mathrm{e}$ & $79.0 \mathrm{~cd}$ & $132.3 \mathrm{a}$ & $86.4 \mathrm{c}$ \\
\hline & Kuru & $84.9 \mathrm{~d}$ & $98.9 \mathrm{bc}$ & $56.0 \mathrm{~g}$ & $56.6 \mathrm{f}$ & $111.9 \mathrm{~b}$ & $49.0 \mathrm{~g}$ \\
\hline \multicolumn{2}{|c|}{ LSD değeri } & \multicolumn{3}{|c|}{$Y \times Y K \times C ̧: 6.3$} & \multicolumn{3}{|c|}{$Y \times Y K \times C ̧: 9.8$} \\
\hline C.V. (\%) & & \multicolumn{3}{|c|}{4.54} & \multicolumn{3}{|c|}{$7.35^{5}$} \\
\hline
\end{tabular}

**, farklı harfleri takip eden ortalamalar \%1 seviyesinde önemlidir.

Üçlü interaksiyonun önemli bulunduğu bitki başına yaprak sayısı açısından ise en yüksek yaprak sayısı 132.3 ve 124.8 adet ile sırasıyla 2018 ve 2017 yıllarında suluda yetiştirilen Sterk çeşidinde, en düşük yaprak sayısı ise 49.0 adet ile 2018 yılında kuruda yetiştirilen Ultra çeşidinde belirlenmiştir (Çizelge 2). Bu, kuru koşullara göre su stresi yaşanmayan suluda bitkilerin daha iyi bir boylanma ve vejetatif gelişme göstermesinden kaynaklanmış olabilir. Çünkü su, bitkilerde hücre bölünmesini ve fotosentezi arttırarak, vejetatif gelişmeyi teşvik eden önemli bir çevre faktörüdür (Sağlam, 2004). Ayrıca Tanzin (2018) Amarant çeşitlerinin bitki boyu ile bitki başına yaprak sayısı arasında önemli ve pozitif bir korelasyonun olduğunu rapor etmiştir. 2017 yılında kuru koşullara göre suluda Helios, Sterk ve Ultra çeşitlerinin yaprak sayısı sırasıyla \%8.6, \%41.4 ve \%58.0 oranında artış gösterirken, 2018 yılında \%28.3, \%15.4 ve \%43.3 oranında bir artış göstermiştir. Dolayısıyla çeşitlerin yıllara ve yetişme koşullarına göre farklı tepki vermesi yaprak sayısı açısından üçlü interaksiyonun önemli çıkmasına neden olmuş olabilir.

\section{Sap Kalınlığı (mm)}

Yürütülen bu araştırmada sap kalınlığı üzerine yılların önemli bir etkisi bulunmazken, yetişme koşulları ve çeşitlerin etkisi \%1 ihtimal seviyesinde önemli bulunmuştur (Çizelge 3). Yetişme koşulları açısından en yüksek sap kalınlığı 21.25 mm ile sulu koşullarda, en düşük değer ise $17.42 \mathrm{~mm}$ ile kuruda belirlenmiştir. Bu beklenen bir sonuçtur. Nitekim bitkilerde büyümenin (boyca uzama ve hacimce genişleme) olabilmesi için hücre bölünmesinin 
gerçekleşmesi, bunun için de hücre içerisine yeterli miktarda suyun girmesi gerekmektedir (Gençtan, 2016). Tersi durumda hücre bölünmesi ve genişlemesi olmayacağından (Taiz ve Zeiger, 2008), sap (gövde) kalınlığı azalmaktadır (Gallardo ve ark., 2004; Liu ve Stutzel, 2004). Dolayısıyla sulama bitkilerde büyümeyi teşvik eden ve arttıran önemli bir çevre faktörüdür.

Çeşitler açısından incelendiğinde, en yüksek sap kalınlığı 25.33 mm ile Helios çeşidinde, en düşük sap kalınlığı ise $9.72 \mathrm{~mm}$ ile Ultra çeşidinde tespit edilmiştir (Çizelge 3). Çeşitlerin genetik yapısı ve çevre koşullarına tepkilerinin farklı olması buna neden olmuş olabilir. Farklı amarant türleri ile yürütülen çalışmalarda da sap kalınlıklarının farklılık gösterdiğini ve çeşitlerin sap kalınlıklarının 15 mm ile 25 mm arasında değiştiğini ifade etmişlerdir (Casini ve Rocca, 2014; Rahnama ve Safaeie, 2017).

Çizelge 3. Sulu ve kuru koşullarda yetiştirilen amarant çeşitlerinin ortalama sap kalınlıkları. Table 3. The mean stem thicknesses of amarant varieties grown in irrigated and dry conditions.

\begin{tabular}{|c|c|c|c|c|c|}
\hline \multirow[b]{2}{*}{ Yıllar } & \multirow[b]{2}{*}{ Yetişme koşulları } & \multicolumn{3}{|c|}{ Çeşitler } & \multirow[b]{2}{*}{ Yılların ortalaması } \\
\hline & & Helios & Sterk & Ultra & \\
\hline \multirow{2}{*}{2017} & Sulu & 26.63 & 24.10 & 9.77 & \multirow{2}{*}{18.15} \\
\hline & Kuru & 22.20 & 18.57 & 7.63 & \\
\hline \multirow{2}{*}{2018} & Sulu & 28.13 & 25.67 & 13.20 & \multirow{2}{*}{20.52} \\
\hline & Kuru & 24.37 & 23.50 & 8.27 & \\
\hline \multicolumn{2}{|c|}{ Çeşitlerin ortalaması } & $25.33 a^{* *}$ & $22.96 \mathrm{~b}$ & $9.72 \mathrm{c}$ & \\
\hline \multicolumn{2}{|c|}{ Yetişme Koşulların ortalaması } & Sulu & $21.25 a^{* *}$ & Kuru & $17.42 \mathrm{~b}$ \\
\hline \multicolumn{2}{|l|}{ LSD değeri } & \multicolumn{4}{|c|}{ Yıl: ö.d., Yetişme koşulu: 1.20, Çeşit: 1.47} \\
\hline \multicolumn{2}{|l|}{ C.V. (\%) } & \multicolumn{4}{|c|}{8.79} \\
\hline
\end{tabular}

**, aynı satırda farklı harfleri takip eden ortalamalar \%1 seviyesinde önemlidir.

\section{Yaş Ot ve Kuru Ot Verimi (kg da $\left.{ }^{-1}\right)$}

Yaş ot ve kuru ot verimi üzerine yıl x yetişme koşulu x çeşit interaksiyonun etkisi sırasıyla \%1 ve \%5 seviyesinde önemli bulunmuştur (Çizelge 4).

Çizelge 4. Sulu ve kuru koşullarda yetiştirilen amarant çeşitlerinin yaş ot ve kuru ot verimleri.

Table 4. The fresh and dry herbage yields of amarant varieties grown in irrigated and dry conditions.

\begin{tabular}{|c|c|c|c|c|c|c|c|}
\hline \multirow{3}{*}{ Yıllar (Y) } & \multirow{3}{*}{ Yetişme koşulları (YK) } & \multicolumn{3}{|c|}{ Yaş ot verimi $\left(\mathrm{kg} \mathrm{da}^{-1}\right)$} & \multicolumn{3}{|c|}{ Kuru ot verimi $\left(\mathrm{kg} \mathrm{da}^{-1}\right)$} \\
\hline & & \multicolumn{3}{|c|}{ Çeşitler (Ç) } & \multicolumn{3}{|c|}{ Çeşitler (Ç) } \\
\hline & & Helios & Sterk & Ultra & Helios & Sterk & Ultra \\
\hline \multirow{2}{*}{2017} & Sulu & $5304.5 b^{* *}$ & $5441.3 \mathrm{bc}$ & $1327.6 \mathrm{f}$ & $880.2 c^{*}$ & $946.9 \mathrm{c}$ & $277.6 \mathrm{e}$ \\
\hline & Kuru & $2503.4 \mathrm{e}$ & 2194.6 e & $568.6 \mathrm{~g}$ & $461.5 \mathrm{~d}$ & $553.3 d$ & $104.4 \mathrm{f}$ \\
\hline \multirow{2}{*}{2018} & Sulu & $5762.1 \mathrm{~b}$ & 7269.8 a & $2268.0 \mathrm{e}$ & $1113.6 \mathrm{~b}$ & 1350.3 a & $490.3 d$ \\
\hline & Kuru & $4949.3 \mathrm{c}$ & $3910.0 \mathrm{~d}$ & $694.2 \mathrm{~g}$ & $888.2 \mathrm{c}$ & $832.9 \mathrm{c}$ & $117.5 \mathrm{f}$ \\
\hline LSD değeri & & \multicolumn{3}{|c|}{ Y x YK x Ç: 573.8} & \multicolumn{3}{|c|}{ Y x YK x Ç: 134.4} \\
\hline C.V. (\%) & & \multicolumn{3}{|c|}{9.43} & \multicolumn{3}{|c|}{11.62} \\
\hline
\end{tabular}

${ }^{* *}$ ve *, farklı harfleri takip eden ortalamalar sırasıyla \%1 ve \%5 seviyesinde önemlidir.

Çizelge 4 incelendiğinde, sulu koşullarla kıyaslandığında kuruda Helios ve Sterk çeşitlerinin yaş ve kuru ot verimleri 2017 yılına göre 2018 yılında daha düşük bir oranda azalma gösterirken, Ultra çeşidinin ise daha yüksek bir oranda azalma gösterdiği görülmüştür. Buna göre en yüksek yaş ot $\left(7269.8 \mathrm{~kg} \mathrm{da}^{-1}\right)$ ve kuru ot (1350.3 kg da$\left.{ }^{1}\right)$ verimleri 2018 yılında sulu koşullarda yetiştirilen Sterk çeşidinde, en düşük değerler ise her iki yılda da kuruda yetiştirilen Ultra çeşidinde belirlenmiştir. Bu sonuçlar Svirskis (2003) ve Abbasi ve ark. (2018) tarafından rapor edilen yaş ot $\left(7000 \mathrm{~kg} \mathrm{da}^{-1}\right)$ ve kuru ot $\left(1320 \mathrm{~kg} \mathrm{da}^{-1}\right)$ verimleri ile benzerlik göstermektedir. 2018 yılının 2017 yılına göre daha ı ıman geçmesi ve kuru koşullara göre suluda kuraklık stresinin daha az olması, bitkilerin daha gümrah bir şekilde gelişmesine neden olabilmektedir. Nitekim Amarant türleri ile öncesinde yürütülen çalışmalarda, kuraklık stresinin artmasıyla çeşitler arasında verimlerin farklılık gösterdiği ve önemli düşüşlerin yaşandığı ortaya konulmuştur (Da Silva ve ark., 2019; Grantz ve ark., 2019). Çünkü su yetersizliği, bitkilerin topraktan besin elementi alımını, taşınmasını ve mineralizasyonunu azaltmaktadır (Bloem ve ark., 1992; Seiffert ve ark., 1995; Garg, 2003). Yine kuru koşullarda artan transpirasyonla birlikte bitkiler kaybettiği suyu alamamakta, bunun sonucu olarak da fotosentez ve dolayısıyla organik madde üretimi azalmaktadır (Öztürk ve Seçmen, 1992; Kalefetoğlu ve Ekmekçi, 2005). Ayrıca diğer çeşitlerle kıyaslandığında Sterk çeşidinin en geçci çeşit olması, ortam koşullarından daha uzun süre istifa etmesine ve daha fazla kuru madde oluşturmasına neden olabilmektedir. Dolayısıyla çeşitlerin farkı genetik yapıya sahip olması, çeşitlerin yıllara göre değişen iklim özellikleri ve yetişme koşullarına farklı tepki vermesi yıl x yetişme koşulu x çeşit interaksiyonun önemli çıkmasına neden olmuş olabilir. Nitekim Ahrar ve ark. 
(2020) topraktaki nemin \%50, \%60, \%70 ve \%80'i tüketildiğinde yapılan sulama ile yem amacılla kullanılan Amarant genotiplerinin yaş ve kuru ot verimlerinin farklılık gösterdiğini ortaya koymuşlardır. Yürütülen bu çalışmada araştırmacılar en yüksek yaş ot $\left(5840 \mathrm{~kg} \mathrm{da}^{-1}\right)$ ve kuru ot $\left(814 \mathrm{~kg} \mathrm{da}^{-1}\right)$ verimlerini su stresi yaşanmayan (topraktaki nemin \%50'si tükendiğinde yapılan sulamada) koşullarda yetiştirilen Loura çeşidinde, en düşük yaş (1788 $\mathrm{kg} \mathrm{da}^{-1}$ ) ve kuru ot (316 kg da-1) verimlerini ise şiddetli su stresinin yaşandığı (topraktaki nemin \%80'i tükendiğinde yapılan sulamada) ortamda yetiştirilen Kharkovski çeşidinden alındığını belirtmişlerdir.

\section{Kuru Ot Oranı (\%)}

Mevcut çalışmada kuru ot oranı yıl $x$ yetişme koşulu $(P \leq 0.05)$, yıl $x$ çeşit $(P \leq 0.05)$ ve yetişme koşulu $x$ çeşit $(P \leq$ 0.01 ) interaksiyonu açısından önemli farklılıklar göstermiştir (Şekil 1). Yıl x yetişme koşulu açısından en yüksek kuru ot oranı 2017 yılındaki kuru (\%20.7) koşullardan, en düşük oran ise 2017 yılındaki sulu (\%18.3) ve 2018 yllındaki kuru (\%18.7) koşullardan alınmıştır (Şekil 1a). Yem Amarant çeşitleri ile yürütülen bir çalışmada da kuraklık stresi arttıkça kuru ot oranlarının artış gösterdiği rapor edilmiştir (Ahrar ve ark., 2020). Şekil 1a incelendiğinde, kuru ot oranı 2018 yılına göre 2017 yılında kuruda \%9.56 oranında artış gösterirken, suluda \%8.31 oranında azalış gösterdiği görülmüş, bu da yıl x yetişme koşulu interaksiyonun önemli çıkmasına neden olmuştur. Bu, 2017 yılının 2018 yılına göre daha kurak geçmesi ve kuruda su stresinin daha fazla olmasından kaynaklanmış olabilir. Nitekim bitkiler su sıkıntısının olmadığı topraklarda bünyelerinde daha fazla su bulundurmakta, tersi durumda ise kuru madde yoğunluğu daha fazla olmaktadır (Amede ve ark., 2003).

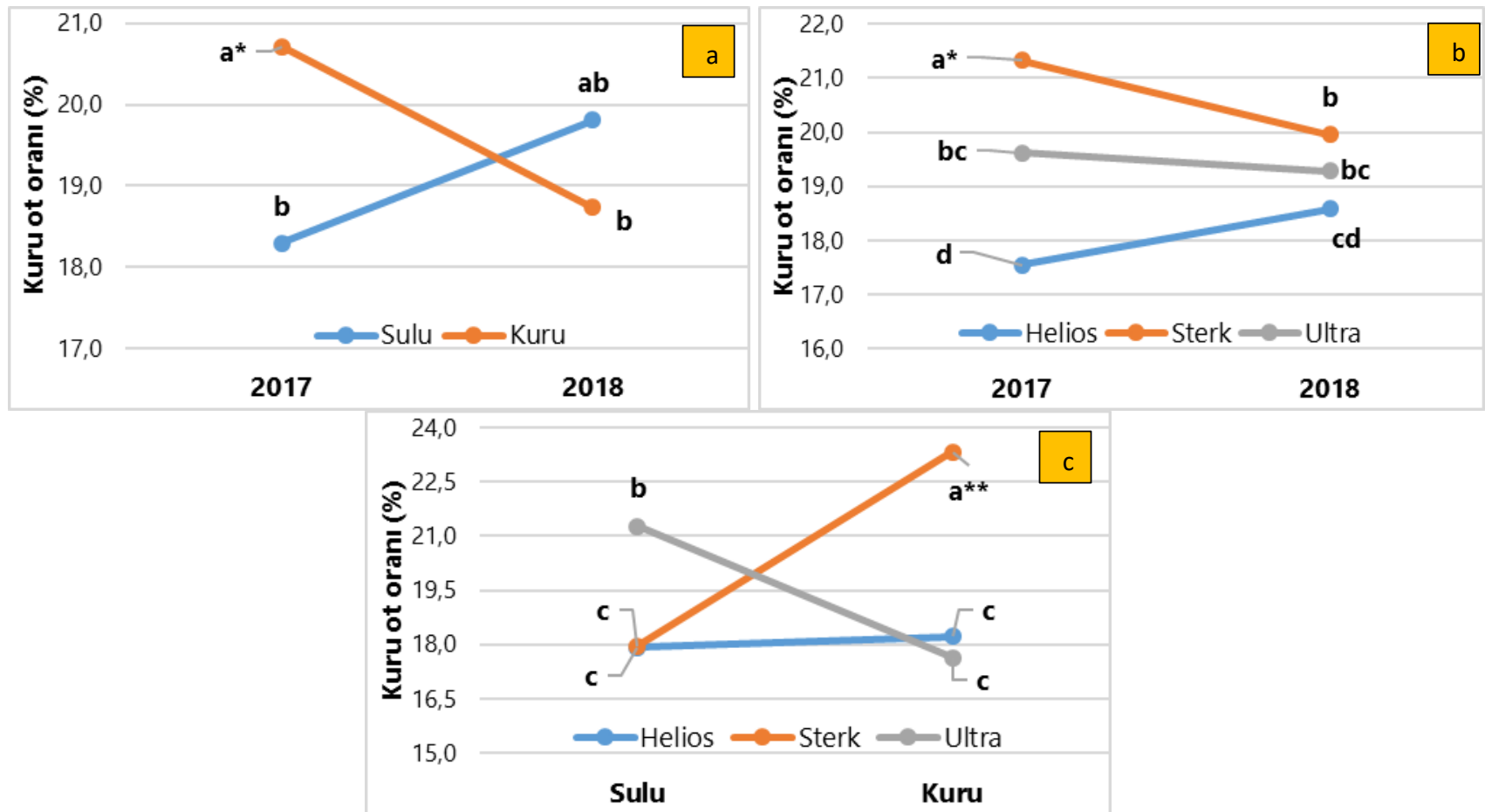

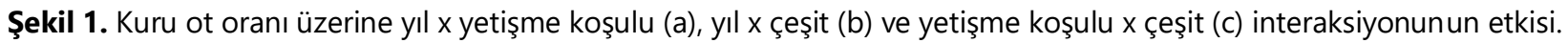

Figure 1. The effect of year $x$ growing condition (a), year $x$ variety (b) and growing condition $x$ variety (c) interaction on the dry herbage ratio.

* ve ** Farklı harfleri takip eden çizimler sırasıyla \%5 ve \%1 seviyesinde önemlidir.

Yıl x çeşit interaksiyonu açısından değerlendirildiğinde, 2017 yılına göre 2018 yılında Ultra çeşidinin kuru ot oranı değişmezken, Sterk çeşidinin kuru ot oranı azalmış, Helios çeşidinin kuru ot oranı ise artmıştır (Şekil 1b). Bu da, yıl x çeşit interaksiyonunun önemli çıkmasına neden olmuştur. Buna göre en yüksek kuru ot oranı (\%21.3) 2017 yılında ekilen Sterk çeşidinde, en düşük oran (\%17.6) ise 2017 yılında yetiştirilen Helios çeşidinde belirlenmiştir (Şekil 1b). Konu ile ilgili olarak Ahrar ve ark. (2020) tarafından yürütülen çalışmada da çeşitlerin kuru madde oranlarının \%15.81-16.47 arasında değiştiğini, ancak istatisitiki olarak önemli bir farklılığın oluşmadığını ifade etmişlerdir. 2017 yılının 2018 yılına göre daha kurak geçmesi ve Sterk çeşidinin geçci bir çeşit olması buna neden olmuş olabilir. Ayrıca yıllara göre ekim ve biçim zamanlarının farklı tarihlerde yapılmış olması, çeşitlerin ortam koşullarına farklı sürelerde maruz kalmasına neden olabilmektedir. Bu da kuru ot oranı açısından çeşitlerin yıllara göre farklı tepki vermesine neden olmaktadır. Yetişme koşulu x çeşit interaksiyonu açısından incelendiğinde, kuru koşullara göre suluda Helios çeşidinin kuru ot oranı değişmezken, Ultra çeşidinin kuru oranı artış göstermiş, Sterk çeşidinin kuru ot oranı ise azalış göstermiştir (Şekil 1c). Bu da yetişme koşulu x çeşit interaksiyonun önemli 
çıkmasına neden olmuştur. Buna göre en yüksek kuru ot oranı \%23.3 ile kuruda yetiştirilen Sterk çeşidinde belirlenirken, en düşük oran hem sulu hem de kuruda yetiştirilen Helios çeşidi ile suluda yetiştirilen Sterk ve kuruda ekilen Ultra çeşitlerinde belirlenmiştir. Çeşitlerin yetişme koşullarına farklı tepki göstermesi yanında kuruda stres koşullarının daha fazla olması buna neden olmuş olabilir.

\section{Yaprak Oranı (\%)}

Yaprak oranı, yaprak ağırığının bitki kısımlarının (yaprak, sap ve salkım) toplam ağılığına oranı olarak ifade edilmekte olup yem kaynağı olarak kullanılan bitkilerde bu oranın yüksek olması arzu edilir. Çünkü yaprak kısımları diğer kısımlara göre daha yüksek besin içeriğine sahiptir (Önal Aşcı ve Acar, 2018). Yürtülen bu çalışmada yaprak oranı üzerinde yıl x çeşit ve yetişme koşulu x çeşit interaksiyonuni \%1 seviyesinde önemli bulunmuştur (Şekil 2). Yıl X çeşit interaksiyonu açısından incelendiğinde, 2017 yılına göre 2018 yılında Sterk ve Ultra çeşitlerinin yaprak oranı daha düşük bir oranda artış gösterirken, Helios çeşidinin daha yüksek bir oranda artış gösterdiği saptanmıştır. Bu da yıl x çeşit interaksiyonunun önemli çıkmasına neden olmuştur. Buna göre en yüksek yaprak oranı 2018 yılında yetiştirilen Helios (\%36.8) ve Sterk (\%36.0) çeşitlerinde, en düşük oran ise 2017 yılında ekilen Helios (\%29.3) ve Ultra (\%30.4) çeşitlerinde belirlenmiştir (Şekil 2a). Oluşan bu farklıık, 2018 yılının 2017 yılına göre daha yağışlı geçmesi ve Ultra çeşidine göre Helios ve Sterk çeşitlerinin daha geçci olmalarından kaynaklanmış olabilir. Çünkü daha az stres koşullarına maruz kalan ve daha uzun gelişme süresine sahip bitkiler gelişmelerini optimum seviyede yapabilmekte ve daha fazla vejetatif aksam oluşturabilmektedirler (Temel ve Tan, 2002; Taiz ve Zeiger, 2008).

Yetişme koşulu x çeşit interaksiyonu açısından değerlendirildiğinde, sulu koşullara göre kuruda Sterk çeşidinin yaprak oranı \%18.0 oranında azalış gösterirken, Ultra çeşidinin ise iki kat daha fazla (\%37.9) bir azalış gösterdiği görülmüştür. Bu da, yetişme koşulu x çeşit interaksiyonunun önemli çıkmasına neden olmuş olabilir (Şekil 2b). Şekil $2 b$ incelendiğinde, suluda yetiştirilen tüm çeşitlerin yaprak oranları en yüksek seviyede olurken, kuruda yetiştirilen Ultra çeşidinin yaprak oranı ise en düşük seviyede kaldığı görülmüştür. Bu, Ultra çeşidinin diğer çeşitlere erkenci olması ve stres koşullarının daha az yaşandığı suluda bitkilerin daha gümrah bir şekilde gelişmesinden kaynaklanmış olabilir. Ayrıca bitki başına yaprak sayısının yüksek olması yaprak ağırlığını ve dolayısıyla yaprak oranının yüksek çıkmasına neden olmuş olabilir. Çünkü Tanzin (2018) yaprak ağırlığı ile bitki başına yaprak sayısı arasından önemli ve pozitif bir ilişkinin olduğunu belirtmiştir. Nitekim yürütülen bu çalışmada sulu koşullara göre kuruda, diğer çeşitlere göre Ultra çeşidinin bitki başına yaprak sayısı en düşük seviyede ölçülmüştür (Çizelge 2).
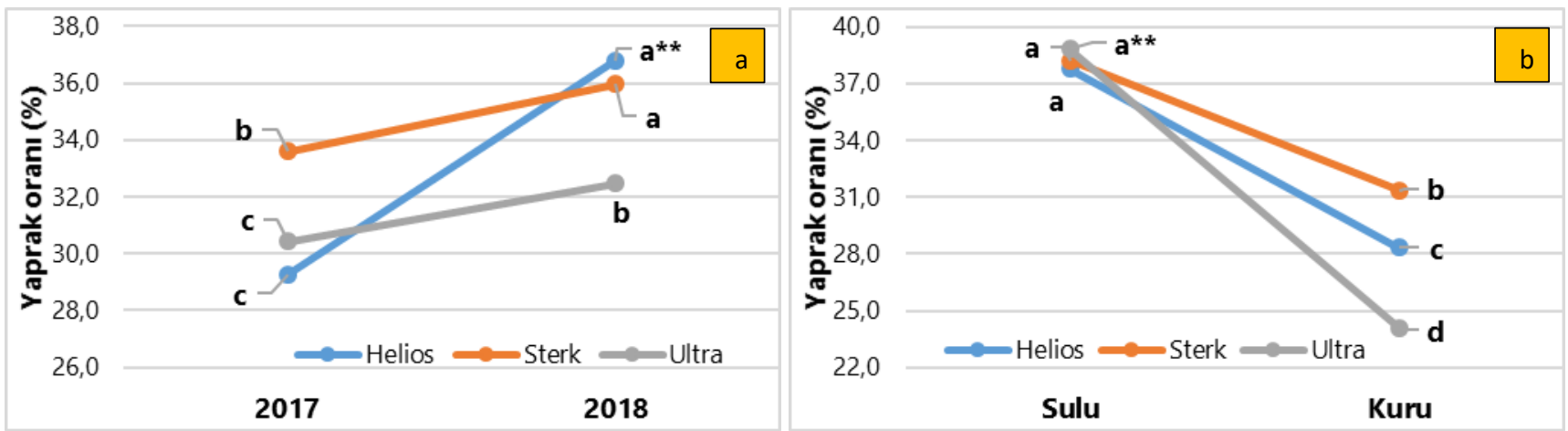

**Farklı harfleri takip eden çizimler \%1 seviyesinde önemlidir.

Şekil 2. Yaprak oranı üzerine yıl $x$ çeşit (a) ve yetişme koşulu $x$ çeşit (b) interaksiyonun etkisi.

Figure 2. The effect of year $x$ variety (a) and growing condition $x$ variety (b) interaction on the leaf ratio.

\section{Sap ve Salkım Oranı (\%)}

Araştırmada üçlü interaksiyonların sap ve salkım oranı üzerine etkisi istatistiki olarak \%1 seviyesinde önemli farklılık göstermiştir (Çizelge 5). Yıl x yetişme koşulu x çeşit interaksiyonunun önemli bulunduğu sap oranında en yüksek oran her iki yılda da kuruda yetiştirilen Helios çeşidinde, en düşük oran ise 2017 yılında kuruda yetiştirilen Ultra çeşidinde (\%28.33) ölçülmüştür (Çizelge 5). Diğer çeşitlere göre Helios çeşidinin sap kalınlığının fazla olması (Çizelge 3) ve her iki yılda kuruda yetiştirilen Helios çeşidinin bitki başına yaprak sayısının düşük olması, buna neden olmuş olabilir. Çünkü sap ağılığı ile sap kalınlığı arasında pozitifi bir ilişki bulunmaktadır (Tanzin, 2018). Her iki yılda da Ultra çeşidinin sap oranı sulu koşullara göre kuruda azalış gösterirken, Helios ve Sterk çeşitlerinin sap oranı artış göstermiştir. Bu da, sap oranı açısından üçlü interaksiyonlarının önemli çıkmasına neden olmuştur. Salkım oranı açısından değerlendirildiğinde, sulu koşullara göre kuruda Helios ve Ultra çeşitlerinin salkım oranı her iki yılda da artış gösterirken, Sterk çeşidinin 2017 yılında \%20.1 oranında bir azalış, 2018 yılında ise \%5.8 
oranında bir artış gösterdiği görülmüştür. Oluşan bu farklııklar salkım oranı açısından yıl x yetişme koşulu x çeşit interaksiyonun önemli çıkmasına neden olmuş olabilir. Buna göre en yüksek salkım oranı \%48.33 ile 2017 yılında kuruda yetiştirilen Ultra çeşidinde, en düşük oran ise \%6.53 ile 2018 yılında suluda yetiştirilen Helios çeşidinde belirlenmiştir (Çizelge 5). Ultra çeşidinin diğer çeşitlere göre daha erkenci olması, 2017 yılının 2018 yılına göre daha kurak geçmesi ve nem yetersizliğinden dolayı bitkilerin sulu koşullara göre kuruda daha erken dönemde hasat olgunluğuna gelmesi, sap ve salkım oranlarının farklı çıkmasına neden olmuş olabilir. Çünkü stres koşullarına maruz kalan ve erkenci özelliğe sahip çeşitler yeterli bir vejetatif gelişme sağlamadan generatif aşamaya geçme eğilimindedirler. Bunun sonucu olarak da bitkiler daha düşük bir boylanma ve sap kalınlığına, sonuçta ise daha düşük bir sap verimi ve daha yüksek bir salkım ağırlığına sahip olabilmektedirler. Nitekim yürütülen mevcut çalışmada da sulu koşullara göre kuruda, Ultra çeşidinin diğer çeşitlere göre daha düşük bir boylanma ve sap kalınlığına sahip olduğu görülmüştür (Çizelge 2; Çizelge 3).

Çizelge 5. Sulu ve kuru koşullarda yetiştirilen amarant çeşitlerinin sap ve salkım oranları.

Table 5. The stem and panicle ratios of amarant varieties grown in irrigated and dry conditions.

\begin{tabular}{|c|c|c|c|c|c|c|c|}
\hline \multirow{3}{*}{ Yıllar (Y) } & \multirow{3}{*}{ Yetişme koşulları (YK) } & \multicolumn{3}{|c|}{ Sap oranı (\%) } & \multicolumn{3}{|c|}{ Salkım oranı (\%) } \\
\hline & & \multicolumn{3}{|c|}{ Çeşitler (Ç) } & \multicolumn{3}{|c|}{ Çeşitler (Ç) } \\
\hline & & Helios & Sterk & Ultra & Helios & Sterk & Ultra \\
\hline \multirow{2}{*}{2017} & Sulu & $55.53 \mathrm{~b} * *$ & $43.87 \mathrm{e}$ & $34.47 \mathrm{f}$ & $10.77 \mathrm{~h} \mathrm{I}^{* *}$ & $19.10 \mathrm{e}$ & $28.00 \mathrm{c}$ \\
\hline & Kuru & $58.90 \mathrm{a}$ & $54.60 \mathrm{~b}$ & $28.33 \mathrm{~g}$ & $16.20 \mathrm{f}$ & $15.27 \mathrm{fg}$ & $48.33 \mathrm{a}$ \\
\hline \multirow{2}{*}{2018} & Sulu & $51.70 \mathrm{c}$ & $48.47 \mathrm{~d}$ & $36.87 f$ & $6.53 \mathrm{j}$ & $12.17 \mathrm{hı}$ & $23.03 \mathrm{~d}$ \\
\hline & Kuru & $58.37 \mathrm{a}$ & $54.57 \mathrm{~b}$ & $36.07 \mathrm{f}$ & 9.831 & $12.87 \mathrm{gh}$ & $39.03 \mathrm{~b}$ \\
\hline LSD değeri & & \multicolumn{3}{|c|}{ Y x YK x Ç: 2.54} & \multicolumn{3}{|c|}{ Y $\times$ YK $\times$ Ç: 2.74} \\
\hline C.V. (\%) & & \multicolumn{3}{|c|}{3.14} & \multicolumn{3}{|c|}{2.74} \\
\hline
\end{tabular}

**, farklı harfleri takip eden ortalamalar \%1 seviyesinde önemlidir.

\section{SONUÇ}

İki yıl süreyle yürütülen mevcut çalışmada; yetişme koşullarına (sulu ve kuru) göre çeşitlerin bitki boyu 44.5$119.4 \mathrm{~cm}$, bitki başına yaprak sayısı 28.8-132.3 adet, sap kalınlığı 7.63-28.13 mm, yaş ot verimleri 568.6-7269.8 kg $\mathrm{da}^{-1}$, kuru ot verimleri 104.4-1350.3 kg da ${ }^{-1}$, kuru ot oranları \%17.55-23.32, yaprak oranları \%24.10-36.80, sap oranları \%28.33-58.90 ve salkım oranları \%6.53-48.33 arasında değişim göstermiştir. İncelenen parametreler göz önüne alındığında en yüksek yaş ve kuru ot verimlerinin Sterk ve Helios çeşitlerinden alındığı ortaya konulmuştur. Ayrıca ot verimine önemli katkısı olan bitki başına yaprak sayısı ve yaprak oranı yine en yüksek bu iki çeşitte belirlenmiştir. Yetişme koşulları açısından ise kuru ot, sap ve salkım oranı hariç incelenen diğer özelliklerin hepsi sulu koşullarda daha yüksek bulunmuştur. Bu sonuçlara göre yüksek ot üretimleri için Sterk ve Helios çeşitlerinin sulu koşullarda yetiştirilmesinin uygun olduğu sonucuna varılmıştır. Ayrıca kuruda yetiştirilen Sterk ve Helios çeşitlerinin azımsanmayacak oranda sırasıyla $3052-3726 \mathrm{~kg} \mathrm{da}^{-1}$ yaş ot ve $693-694 \mathrm{~kg} \mathrm{da}^{-1} \mathrm{kuru}$ ot verimlerine sahip oldukları belirlenmiştir. Sonuç olarak sulu koşullara göre kuruda çeşitlerin ot verimleri önemli oranda düşüş gösterse de her iki yetişme koşulunda da Sterk ve Helios çeşitlerinin tercih edilmesinin uygun olacağına karar verilmiştir.

\section{ÇIKAR ÇATIŞMASI}

Makale yazarları arasında herhangi bir çıkar çatışması bulunmamaktadır.

\section{YAZAR KATKISI}

Yazarlar makaleye eşit oranda katkı sağlamışlardır.

\section{KAYNAKLAR}

Abbasi, D., Rouzbehan, J., \& Rezaei, J. (2012). Effect of harvest date and nitrogen fertilization rate on the nutritive value of amaranth forage (Amaranthus hypochondriacus). Animal Feed Science and Technology, 171, 6-13.

Abbasi, M., Rouzbehan, Y., Rezaei, J., \& Jacobsen, S. E. (2018). The efect of lactic acid bacteria inoculation, molasses, or wilting on the fermentation quality and nutritive value of amaranth (Amaranthus hypochondriaus) silage. Journal of Animal Science 96, 3983-3992 
Acar, Z., Sancak, C., \& Genç, N. (1999). Horoz İbiği (Amaranthus) 'nin Önemi ve Kullanımı. Ekin dergisi, 3(8), 71-74.

Adhikary, D., Khatri-Chhetri, U., \& Slaski, J. (2020). Amaranth: An Ancient and High-Quality Whole some Crop. In Nutritional Value of Amaranth. Intech Open.

Ahrar, A., Paknejad, F., Tabatabaei, S. A., Aghayari, F., \& Soltani, E. (2020). Evaluation of forage Amaranth (Amaranthus hypochondriacus L.) yield via comparing drought tolerance and susceptibility indices. Italian Journal of Agrometeorology, 3, 31-40.

Alegbejo, J.O. (2013). Nutritional value and utilization of amaranthus (Amaranthus spp.)-a review. Bayero journal of pure and applied sciences, 6, 136-143.

Amede, T., Schubert, S., \& Stahr, K. (2003). Mechanisms of drought resistance in grain legumes, I: Osmotic Adjustment. Ethiopian Journal of Science and Technology, 26(1), 37-46.

Anjum, S. A., Xie, X. Y., Wang, L. C., Saleem, M. F., Man, C., \& Lei, W. (2011). Morphological, physiological and biochemical responses of plants to drought stress. African Journal of Agricultural Research, 6(9), 2026-2032.

Bloem, J., De Ruiter, P. C., Koopman, G. J., Lebbink, G., \& Brussaard, L. (1992). Microbial numbers and activity in dried and rewetted arable soil under integrated and conventional management. Soil Biology and Biochemistry, 24, 655-665.

Casini, P., \&, Rocca, F. L. (2014). Amaranthus cruentus L. is suitable for cultivation in Central Italy: field evaluation and response to plant densities. Italian Journal of Agronomy, 9(602), 166-175.

Da Silva, J. G., Bianchini, A., Costa, P. M. C., de Almeida Lobo, F., de Almeida, J. P. M., \& de Moraes, M. F. (2019). Amaranth response to water stress. Journal of Experimental Agriculture International, 1-9.

Dlamini, S. N., Masarirambi, M. T., Wahome, P. K., \& Oseni, T. O. (2020). The Effects of organic fertilizers on the growth and yield of Amaranthus (Amaranthus hybridus L.) grown in a lath house. Asian Journal of Advances in Agricultural Research, 1 10.

Dumanoğlu, Z., \& Geren, H. (2019). Effect of different nitrogen and phosphorus levels on the herbage yield and some silage characteristics of Amaranth (Amaranthus mantegazzianus). Ege Üniversitesi Ziraat Fakültesi Dergisi, 56(1), 45-52.

Fazaeli, H., Ehsani, P., Safayee, A. R., \& Mehrani, A. (2011). Amaranth (Amaranthus hypochondriacus) as a new forage source. $V^{\text {th }}$ Internatıonal Conference: Balnimalcon, 20 October 2011, Bucharest, Romania.

Garg, B. K. (2003). Nutrient uptake and management under drought: Nutrient-moisture interaction. Current Agriculture Research Journal, 27(1/2), 1-8.

Gallardo, M., Thompson, R. B., Valdez, L. C., \& Pêrez, C. (2004). Response of stem diameter to water stress in greenhousegrown vegetable crops. Acta Horticulturae, 664, 253-260.

Gao, S., Wang, Y., Yu, S., Huang, Y., Liu, H., Chen, W., \& He, X. (2020). Effects of drought stress on growth, physiology and secondary metabolites of Two Adonis species in Northeast China. Scientia Horticulturae, 259(10), 87-95.

Genç, N., \& Acar, Z. (1999). Horozibiği (Amaranthus sp.)'nin azot ihtiyacının ot ve tohum veriminin ve bazı özelliklerinin belirlenmesi üzerine bir araştırma. Ondokuz Mayıs Üniversitesi Ziraat Fakültesi Dergisi, 14(3), 65-75.

Gençtan, T. (2012). Tarımsal Ekoloji. Namık Kemal Üniversitesi Ders Kitabı. Genel Yayın: 6 Yayın No:3, Tekirdağ.

Goptsiy, T., Voroncov, N., Popov, V., Zhyravel, D., \& Gromenko, S. (2008). Grain varieties of amaranth developed by selection at Kharkiv National Agrarian University and the perspectives of their use. In Amaranth-Plant of the Future: 5th International Symposium of the European Amaranth Association, Nitra, Slovak Republic.

Grantz, D. A., Paudel, R., \& Shrestha, A. (2019). Tolerance of ozone and drought in common waterhemp (Amaranthus tuberculatus). Journal of Crop Improvement, 33(2), 236-253.

Jafari, H. R., Karimi, S., \& Alavipoor, F. S. (2018). Enviromental planning and management. In: The Potential for the Use of Mutant Ornamental Plants for Reclamation of Arid Lands, Cambridge Scholars Publishing.

Kacar, B. (2012). Toprak Analizleri. Nobel Akademik Yayıncılık, Yayın No: 484, Ankara.

Kalefetoğlu, T., \& Ekmekçi, Y. (2005). Bitkilerde kuraklık stresinin etkileri ve dayanıklılık mekanizması. Gazi Üniversitesi Fen Bilimleri Dergisi, 18(4), 723-740.

Khan, M. G., Abate, M., Endris, S., \& Chaka, A. (2019). A Critical appraisal of amaranths and chenopodium weeds for their harmful and beneficial aspects in context to food security in pastoral area. Daagu International Journal of Basic \& Applied Research, 1(1), 58-69.

Leukebandara, I. K., Premaratne, S., \& Peiris, B. L. (2015). Nutritive quality of Thampala (Amaranthus spp.) as a forage crop in Sri Lanka. Tropical Agricultural Research, 26, 624-631. 
Leukebandara, I. K., Premaratne, S., Peiris, B. L., Madugith, T., \& Wimalasiri, S. (2019). Study on milk parameters of saanen goats fed with diet containing Amaranth (Amaranthus Hypochondriacus) seeds. International Journal of Agricultural Science, 4 , 45-56.

Liu, F., \& Stutzel, H. (2004). Biomass partitioning, specific leaf area and water use efficiency of vegetable amaranth (Amaranthus spp.) in response to drought stress. Scientia Horticulturae, 102(1), 15-27.

MGM. (2019). Başbakanlık DMi Genel Müdürlüğü Meteroloji Bültenleri, Ankara.

Mlakar, S. G., Bavec, M., Turinek, M., \& Bavec, F. (2009). Rheological properties of dough made from grain amaranth-cereal composite flours based on wheat and spelt. Czech Journal of Food Science, 27, 309-319.

Myers, R. L. (1998). Nitrogen fertilizer effect on grain amaranth. Agronomy of Journal, 90, 597-602.

Olorunnisomo, O., \& Ayodele, O. (2009). Effects of intercropping and fertilizer application on the yield and nutritive value of maize and Amaranth forage in Nigeria. Grass and Forage Science, 64(4), 413-420.

Önal Aşcı, Ö., \& Acar, Z. (2018). Kaba Yemlerde Kalite. Pozitif Matbaacılık ve Ambalaj Sanayi Ticaret Limited Şirketi, Ankara.

Öztürk, M. A., \& Seçmen, Ö. (1992). Bitki Ekolojisi. Ege Üniversitesi Fen Fakültesi Yayınları No: 141, İzmir.

Peiretti, P. G. (2018). Amaranth in animal nutrition: A review. Livestock Research for Rural Development, 30(5).

Pimentel, D., Marklein, A., Toth, M. A., Karpoff, M., Paul, G. S., McCormack, R., Kyriazis, J., \& Krueger, T. (2008). Biofuel impacts on world food supply: use of fossil fuel, land and water resources, In: Energies 1, 41-78.

Rahnama, A., \& Safaeie, A. R. (2017). Performance comparison of three varieties of amaranth (Amaranthus hypochondriacus L.) at different harvest Time. International Journal of Research Studies in Agricultural Sciences, 3, 1-6.

Rezaei, J., Rouzbehan, Y., Fazaeli, H., \& Zahedifar, M. (2014). Effects of substituting amaranth silage for corn silage on intake, growth performance, dietdigestibility, microbial protein, nitrogen retention and ruminal fermentation in fattening lambs. Animal Feed Science and Technology, 192, 29-38.

Sağlam, A. (2004). Ağır kuraklık stresi geçirmiş Ctenanthe setosa bitkisinin yeni kuraklık koşullarına adaptasyon yeteneğinin araştırılması. Yüksek Lisans Tezi, Karadeniz Teknik Üniversitesi, Fen Bilimleri Enstitüsü, Trabzon.

Sarmadi, B., Rouzbehan, Y., \& Rezaei, J. (2016). Influences of growth stage and nitrogen fertilizer on chemical compositon, phenolics, in situ degradability and in vitro ruminal variables in amaranth forage. Animal Feed Science and Technology, 215, 273-284.

Seiffert, S., Kaselowsky, J., Jungk, A., \& Claassen, N. (1995). Observed and calculated potassium uptake by maize as affected by soil water content and bulk density. Agronomy of Journal, 87, 1070-1077.

Sokoto, M., \& Johnbosco, O. (2017). Growth and yield of Amaranths (Amaranthus spp.) as influenced by seed rate and variety in Sokoto, Nigeria. Archives of Agriculture and Environmental Science, 2(2), 79-85.

Svirskis, A. (2003). Investigation of amaranth cultivation and utilisation in Lithunia. Agronomy Research, 1(2), $253-264$.

Taiz, L., \& Zeiger, E. (2008). Bitki Fizyolojisi. Çeviren: Türkan, İ., Palme Yayıncılık, Ankara, 690s.

Tan, M., \& Temel, S. (2012). Alternatif Yem Bitkileri. Atatürk Üniversitesi Ziraat Fakültesi Ders Yayınları No: 246, Erzurum, 195207.

Tan, M., \& Temel, S. (2017). Erzurum ve Iğdır şartlarında yetiştirilen farklı kinoa genotiplerinin kuru madde verimi ve bazı özelliklerinin belirlenmesi. Iğdır Üniversitesi Fen Bilimleri Enstitüsü Dergisi, 7, 257-263.

Tan, M., \& Temel, S. (2019). Her Yöneyle Kinoa, Önemi, Kullanılması ve Yetiştiriciliği. Iksad Publishing House, Ankara.

Tanzin, T. (2018). Assessment of growth and yield potential of different vegetable amaranth type In Kleve, Germany. Master Thesis, The Faculty of Life Sciences, Hochschule Rhein-Waal University of Applied Sciences, Kleve, Germany.

Temel, S., \& Tan, M. (2002). Erzurum şartlarında adi fiğ (Vicia sativa L.)'in ekim ve hasat zamanlarının belirlenmesi üzerine bir araştırma. Atatürk Üniversitesi Ziraat Fakültesi Dergisi, 33 (4), 363-368.

Venskutonis, P. R., \& Kraujalis, P. (2013). Nutritional components of amaranth seeds and vegetables: A review on composition, properties, and uses, Comprehensive Reviews in Food Science and Safety, 12(4), 381-412.

Yaroshko, O. M., \& Kuchuk, M. V. (2018). Agrobacterium-caused transformation of cultivars Amaranthus caudatus L. and hybrids of $A$. caudatus L. x A. paniculatus L. International Journal of Secondary Metabolite, 5, 312-318.

Yarnia, M., Khorshidi Benam, M. B., Farajzadeh Memari Tabrizi, E., Nobari, N., \& Ahmadzadeh, V. (2011). Effect of planting dates and density in drought stress condition on yield and yield components of Amaranth cv. Koniz. Advances in Environmental Biology, 5 (6), 1139-1149. 